\title{
The Interference of Makassarese Language into Indonesian Language by Mobile Vegetable Traders Towards Buyers in Makassar City: A Socio- Morphological Study
}

\author{
Nurhayati Nurhayati \\ A Lecturer from the Faculty of Cultural Sciences at Universitas Hasanuddin \\ Email:nurhayati@unhas.ac.id
}

\begin{abstract}
This study is entitled the Interference of Makassarese language into the Indonesian language by Mobile Vegetable Traders towards Buyers in Makassar City: A Socio-Morphological Study. This study aims to describe: (1) the forms of morphological interference of Makassarese language into the Indonesian language by the mobile vegetable trader and (2) the factors that affect the occurrence of Makassarese language interference into the Indonesian language by the mobile vegetable trader. This study adopts the observation method with the recording and note-taking technique. The observation method means a method used in language study, in this case, observing the language used by mobile vegetable traders and buyers in Makassar city. While note-taking technique means taking a note about the phenomenon of language use in the transaction between mobile vegetable traders and buyers. The data are analyzed by using qualitative descriptive analysis. The findings show that there are 5 interference forms done by the mobile vegetable trader, such as clitic, particle, interjection, unique morpheme, and word. Meanwhile, 3 factors cause mobile vegetable traders to use interference: they are bilingual speakers, they want to make the intimate situation, and they want to joke with the customers.
\end{abstract}

Keywords: Interference, Vegetable Trader, Buyer

\section{INTRODUCTION}

The Makassar Tribes living in Makassar city have any kind of work, for example, a mobile vegetable trader called Pensake in Makassarese language. These pensake sell their goods by walking along the streets and alleys in Makassar city. Some of them have loyal and regular customers.

Generally, mobile vegetable traders in Makassar city are from the Makassar tribe. So, there will be moments in selling and buying transactions they insert Makassarese language while communicating with the buyers.

The mobile vegetable traders try to attract buyers by using the Indonesian language mixed with the Makassarese language. They speak a lot in persuasive language and are accompanied by humor a little. In addition, they often call the customers sambalu, which means 'customer' in Makassarese language.
The mixing of the Makassarese language and Indonesian language by mobile vegetable traders often happens, particularly if the customers are not from the Makassar tribe. This action aims to make the intimate situation.

There are many mobile vegetable traders with the background of Makassarese language speakers. This kind of condition will lead to bilingualism matter for them, called interference. It occurs since the speaker is an expert in two languages. The entry of the Makassarese language element into other languages is known as 'interference' that is included in the sociolinguistic study.

Interference is found from the speech of the mobile vegetable trader to the buyer. Eventually, the incident of mobile vegetable traders who speak the Makassarese language mixed with the Indonesian language cannot be prevented. It occurs since the mobile vegetable traders have expertise earlier in the Makassarese language rather than the buyers. 
The vocabularies of the Makassarese language enter the Indonesian language when mobile vegetable traders communicate with the customers. The mobile vegetable traders use the vocabularies in the form of words in the Makassarese language, clitics, particles, and interjections.

\section{INTERFERENCE AND MORPHOLOGY THEORY}

Interference is defined as a language error that occurred because of habits in carrying the mother tongue into the second language [1]. The definition of interference is an event of transferring the asset of a language into another language in the form of a language act. Weinreich said interference is the contact of two languages that causes changes conducted by bilingual speakers.

Suwito[2] defined interference occurs in bilingual speakers and is considered as a speech symptom (speech, parole). The event is considered as a deviation. Interference is considered as something not important to occur since the real absorption elements already have an equivalent in the absorption language so that it will be following the development of Jendra [3] divided interference into five aspects:

1. Interference in sound system (phonology)

2. Interference in word formation (morphology)

3. Interference in sentence structure (syntax)

4. Interference in vocabulary (lexicon)

5. Interference in meaning (semantic)

This study adopts the theory of Ramlan which stated morphology means a study concerning word formation and the influence of the changes towards the class of word and meaning of the word. Word formation is distinguished into base word, affixation, reduplication, composition, function, and mening.

The main studies in morphology are morphem, lexem, root, base word, and formed word. They will be a word through the morphology process [4]. For example, the form of "PUKUL" (in the 'morphology' convention, the lexem is written in capital letter) is a lexem that will produce word derivations, which are memukul, terpukul, pukul, pukulan, pemukul, and pemukulan (in the Indonesian language).

\section{RESEARCH METHOD}

The observation method is conducted as the method of data collection. It is a method of observing written and spoken language. Hence, the researcher records the utterances of the vegetable traders and the buyers. Meanwhile, the techniques of data collection used are interview, recording, and notetaking. The interview is applied by giving questions that the vegetable traders and the buyers must answer. The recording is applied by recording the speech of the vegetable traders. Note-taking is applied to note every utterance of the vegetable traders and the buyers.

\section{DISCUSSION}

Interference is defined as a form of language rule deviation because of language contact. There were several references about this case, such as from Nababan [5]. The morphological interferences that happen on the mobile vegetable traders (Pensake) in Makassar city are interference in the form of clitic, particle, interjection, unique morpheme, and word. The interference will be discussed one by one as follow:

\subsection{Morphological Interference}

The definition of morphological interference is a deviation of linguistic form that happens due to lexems (words) and morphems transfer from the first language (Makassarese language) into the second language (Indonesian language). The morphological interferences are in the form of clitic, particle, interjection, unique morphem, and word. The data of the mobile vegetable trader (Pensake) utterance to the buyers is as the following:

a. Clitic Interference

In the book of Teori Linguistik, Markhama et al [6] stated that clitic is a short form (syllable) placed in the initial of word called proclotic and in the end of word called enclitic.

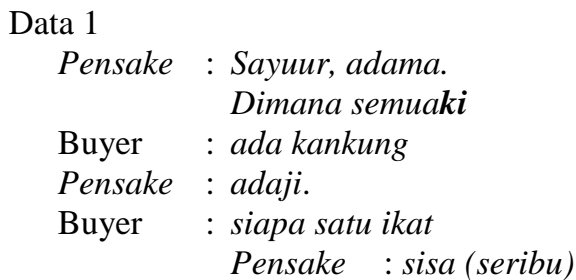

Data 2

$\begin{array}{ll}\text { Pensake : E. sambalu sayur } \\ \text { Buyer } & \text { : Ada tomat? } \\ \text { Pensake } & : \text { Ada } \\ \text { Buyer } & \text { : Mauka } \\ \text { Pensake } & \text { : Berapa mau nubeli } \\ \text { Buyer } & \text { : Tiga ribu }\end{array}$

Data 3

$\begin{array}{ll}\text { Pensake } & \text { : Yur-sayur adama lagi } \\ \text { Buyer } & \text { : Lamana baru datang? } \\ \text { Pensake } & \text { : Maceki. } \\ \text { Buyer } & : \text { Bawajiki sayur kelor } \\ \text { Pensake } & : \text { Iye. } \\ \text { Buyer } & : \text { Berapa satu ikat. Boleh } 200031 \\ & \text { ikat. }\end{array}$

Pensake : Kiambilmi. 
The data above are the example of clitic interference that Makassarese language enter into Indonesian language. At the data 1 , there is an enclitic $-\boldsymbol{k i}$ on the word of semuaki and at the data 2 there is an enclitic $-\boldsymbol{k} \boldsymbol{a}$ on the word of mauka uttered by the buyer, meaning 'I want'. So, in this case, the clitic of $\boldsymbol{k a}$ means ' $\mathbf{I}$ ' and the enclitic $-\boldsymbol{k i}$ means 'You'. Next, on the word of nubeli uttered by pensake means 'You buy'. The proclitic $\boldsymbol{n u}$ on the word of nubeli means 'You'. At the data 3, there is also a proclitic of $\boldsymbol{k i}$ - on the word of kiambilmi which means 'Take it, pelase'.

b. Particle Interference

\section{Data 4}

$\begin{array}{ll}\text { Pensake } & \text { : Sayur-sayuur } \\ \text { Buyer } & : \text { Adami sambalu (sudah ada langganan) } \\ \text { Pesake } & : \text { Adama. (saya sudah ada) } \\ \text { Buyer } & : \text { Adaji sayur nangkanu (adakah sayur } \\ & \text { nagkamu) } \\ \text { Pesake } & : \text { Ada }\end{array}$

Data 5

$\begin{array}{ll}\text { Pensake } & \text { : Assalamualikum } \\ \text { Buyer } & : \text { Walaikumsalam } \\ \text { Pensake } & \text { : Banyak sayur sambalu. } \\ \text { Buyer } & \text { : liat bedeng } \\ \text { Pesake } & \text { : Ada semuami pesananta } \\ \text { Buyer } & \text { : Alhamdulillah. }\end{array}$

Data 6

Pensake : Oh, sambalu

Buyer : Iye sambalu

Pensake : Datangma lagi

Buyer : Sayur apa nubawa

Pensake : Banyak

Buyer : Bisa bongkar

Pensake : Bolehji

The interference at the data 4 above is in the form of particle, that is particle of $-j i$. In Indonesian language, it has same meaning with the particle of lah. The word of adiji means adalah in Indonesian language. At the data 5, the is particle of $-\boldsymbol{m i}$ on the word semuami that means 'All is already there'. At the data 6 , there is the particle of $-j i$ on the word of bolehji which means bolehlah in Indonesian language.

c. Interjection Interference

Interjection interference from the Makassarese language into the Indonesian language done by mobile vegetable traders also happens. Consider the following data:

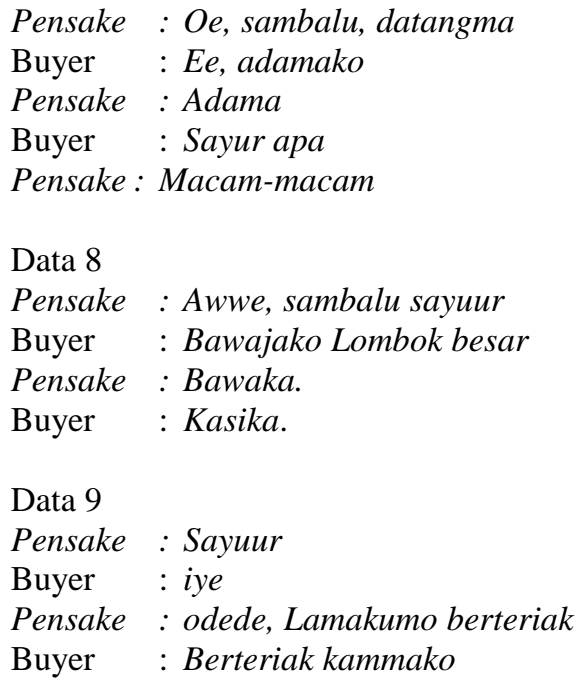

There is the interjection of $\boldsymbol{o} \boldsymbol{e}$ at the data above. This interjection is usually used by Makassar society to call other people. In the Indonesian language, it is translated as 'Halo'. The interjection of awe at data 8 has a function to greet the interlocutor. At data 9, the interjection of odede is commonly used to express something annoying to the interlocutor.

d. Unique Morphem Interference of Makassarese language

There are several unique morphems of Makassarese language that enter into the Indonesian language when the mobile vegetable traders interact with the buyers and vice versa.

Data 10

Buyer : Adami sambalu

Pensake: Iye adama

Buyer : Adaji pesananku

Pesake : Apa itu kulupai seng.

Buyer : Memang tong ini sambalu tukang lupa.

Pesake : Toama kodong. Jadi tukang lupa ma

Data 11

Pensake : Sayur-sayur

Buyer : Sayur apa

Pensake : Macam-macam bedeng

Buyer : Apa itu.

Pensake : Liamaki sendiri gang.

At the data 10 above, there are unique morphem interferences of the Makassarese language that enter into the Indonesian language. It is called a unique morphem since this morpheme only exists in Makassarese language. The word of seng means 'again' and tong means 'also'. At the data 11, there are unique morphemes, namely bedeng that means 'he told' and gang that means 'friend'.

e. Word Interference

Data 7 
Word interference is the word entry of Makassarese language into Indonesian language. Here are the data:

\author{
Data 12 \\ Pesake : Oh, sambalu, Sambaluuu \\ Buyer : Kenapaki naberteriak kamma. \\ Sepertina tidak didengarki. \\ Pesake : Sengaja ka. Keras suaraku biar \\ nudengarki. \\ Buyer : Tenajana natuli. \\ Pesake : Jangki larro.-larro teman
}

Data 13

Pensake : Adama lagi sambalu

Buyer : Apa seng sayurmu.

Pensake : Jai ji

Buyer : Banyakkah?

Pemsake: Tantumi

Data 14

Pensake : Sabaluu, adama lagi.

Buyer : Kanapai kalau niakki.

Pesake : Maraki

Buyer : Tenaja

At the data12, there is the word of kamma which means 'really'. There is also the word of larro-larro that means 'angry'. At the data 13, the word of jai means 'many' and tantu means 'sure'. Meanwhile, there is the word of tenaja at the data 14, meaning 'no.'

\subsection{The Factors that Cause Interference on the Mobile Vegetable Trader}

The cause factors of the mobile vegetable trader interfere while interacting with the buyers are as follow:

1. Bilingualism. It occurs since pesake is one of the people whose expertise in two languages, which are Makassarese language and indonesian language. Generally, Makassar society is bilingual speakers and so the mobile vegetable trader is. Thus, Makassar society often interfere while interacting. The example of the interferences are tantumi (pretty sure); alle saja (just take it); kemae sayurnu (where is your vegetables?); and so forth.

2. Familiarity. The Pensake creates intimacy to the buyers by using interference as one of the ways he does not feel clumsy while communicating. For example, the sentence Janganko larro-larro teman which means janganko mara-marah teman'.

3. Humor. The Pensake interferes because he wants to give the humor effect to his utterance. Then, unique words or morphems appear and contain humor element. For example, rong, sambalu, tong, seng, gang, nah, bisa, adama sambalu, awe interjection, and odede uttered by pensake with showing his facial expression so it makes the buyers feel amused while hearing.

\section{CONCLUSION}

The mobile vegetable traders use interference while interacting with their customers. The interference is in the form of clitic, particle, interjection, unique morphem, and interjection of the word. The factors that affect these interferences are 1) bilingualism, the mobile vegetable traders are bilingual speakers, meaning have expertise in two languages (Makassarese language and Indonesian language). 2) Familiarity, the mobile vegetable traders interfere since they want to create an intimate situation with the buyers, and 3) Humors, the mobile vegetable traders build comfort and fun communication by creating humors.

\section{REFERENCES}

[1] Hartman, R.R.K. dan F.C. Stork. 1972. Dictionary of Language and Linguistics. London: Applied Science Publisher Ltd

[2] Suwito, 1985. Pengantar Awal Sisolinguistik: teori dan Problema. Surakarta: Henry Cipta

[3] Jendra., I Wayan. 1991. Dasar-dasar Sosiolinguistik. Denpasar: Ikayana.

[4] Chaedar, Abdul dan Leonie Agustina.2004. Sosiolinguistik Perkenalan Awal. Jakarta: Asdi Mahatya.

[5] Nabanan. P.W.J. 1984. Sosiolingfuistik. Jakarta: Gramedia.

[6] Markhamah, Sabardila Atiqa, Haryanti Dwi. 2018. Teori LInguistik: Beberapa Aliran Linguistik. Surakarta: Muhammdiyah University Press. 